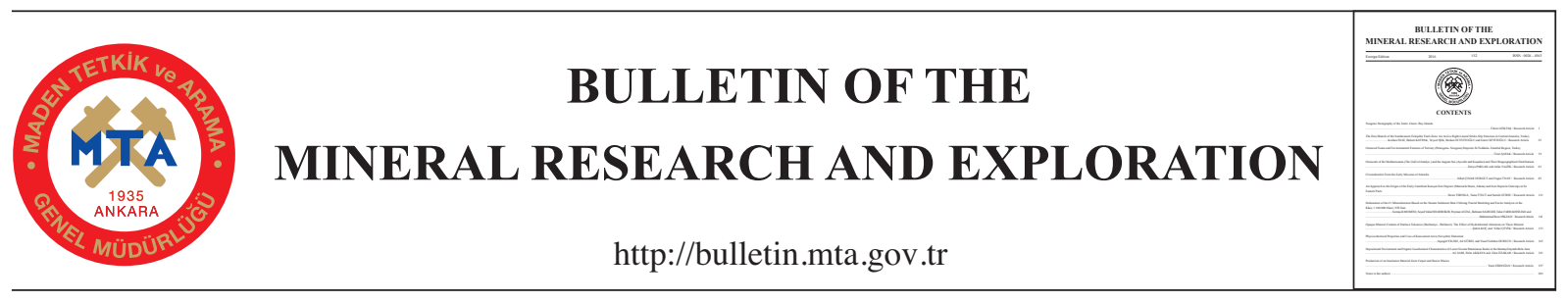

\title{
DELINEATION OF THE CR MINERALIZATION BASED ON THE STREAM SEDIMENT DATA UTILIZING FRACTAL MODELING AND FACTOR ANALYSIS IN THE KHOY 1:100.000 SHEET, NW IRAN
}

\author{
Somayeh Momenia,, , Seyed Vahid Shahrokhia, Peyman Afzal ${ }^{\mathrm{b}, \mathrm{c}}$, Behnam Sadeghi ${ }^{\mathrm{b}, \mathrm{d}, \mathrm{e}}$, \\ Taher Farhadinejad ${ }^{\mathrm{a}}$ and Mohammad Reza Nikzad ${ }^{\mathrm{e}}$ \\ ${ }^{a}$ Department of Geological, Khoramabad Branch, Islamic Azad University, Khorramabad, Iran \\ ${ }^{b}$ Department of Mining Engineering, Faculty of engineering, South Tehran branch, Islamic Azad University, Tehran, Iran \\ ${ }^{c}$ Camborne School of Mines, University of Exeter, Penryn, UK \\ ${ }^{d}$ Department of Earth and Oceans, James Cook University, Townsville, Queensland 4811, Australia \\ ${ }^{e}$ Hampa Behineh Consultant Engineers Co., Tehran, Iran
}

Research Article

Keywords:

Stream Sediments,

Fractal Analysis,

Concentration-Number,

Concentration-Area, Cr,

Khoy, Iran

Received: 18.09 .2014

Accepted:01.06.2015

\begin{abstract}
Fractal methods are regarded as a highly efficient method for more accurate separation of boundaries between mineralized zone in shallow and deep studies. In this research, concentration-number $(\mathrm{C}-\mathrm{N})$ and concentration-area (C-A) fractal methods were used in order to identify promising areas of the elements like Cr, Co and Ni in the Khoy 1:100.000 geological mapping sheet, NW Iran. The factor analysis was performed on the elements, and factors, which were related to the elements, were isolated and studied by both fractal methods. The current geological locations of the extreme anomalies were investigated and the results showed a very close relationship and overlapping. The results of the presented models show that the most elements under study are located in the central and southwestern parts of the sheet. From the point of view of the lithology, these areas correspond to the serpentinite ultramafic units of harzburgite and dunite, and as a result, there is a high probability of $\mathrm{Cr}$ mineralization. The achieved results are confirmed by factor analysis. This means that a factor accumulation of these elements is exactly the same as those of each element.
\end{abstract}

\section{Introduction}

Basically, the separation of the geochemical anomalies from background is very important in order to interpret the mineralized zones (Hassanpour and Afzal, 2013). Anomaly detection and separation are the most important aim in geochemical exploration. The analysis of the histogram is one of the methods which is used in these kinds of studies. Summary statistics such as mean, median, variance, maximum, minimum and standard deviation are calculated in addition to drawing the histograms of the stream sediment samples. The traditional methods can only show the frequency of the elements distribution without any information about the spatial variability and spatial correlation. Furthermore, conventional statistical methods e.g., histogram analysis or Q-Q plots assuming normality or lognormality and do not consider the shape, extent and magnitude of anomalous areas (Rafiee, 2005; Afzal et al., 2010).
The scientists were looking for a way to describe all processes in the nature because the Euclidean geometry uses the discrete and integer numbers which are not capable to the explanation of the most complications of the nature. Hence, Mandelbrot (1983) introduced fractal geometry as a suitable tool so as to describe these problems. Among various methods that have been proposed, the fractal geometry is one of the newest and applicable methods for separation of geochemical anomalies. Turcotte (1986) showed the fact that there is a fractal relationship between the cumulative amounts of a deposit and average grades in different parts of a deposit. Meng and Zhao (1991) expressed the existence of fractal structures in geology. In recent years, fractals and multifractal methods are being used in various branches of the earth sciences such as geophysics and geochemistry. In the analysis of the complex geological structures, especially in the field of economic geology and mining exploration, 
the spatial distributions of the attributes are used. Fractal/multifractal theory may be interpreted as a theoretical framework that descriptions the powerlaw relations between areas enclosing concentrations below a given value and the actual concentrations itself. To demonstrate and prove that data distribution has a multifractal nature requires a rather extensive computation. There is not any relationship between data distribution and fractal/multifractal modelling (Mandelbrot, 1983; Afzal et al., 2010; Mohammadi et al., 2013).

In the fractal geometry, each shape and its complexity are shown in terms of decimal and continuous numbers, and consequently it is an appropriate tool to determine the thresholds. Some of the important and useful fractal methods used in the earth sciences are number-size (N-S: Mandelbrot, 1983; Agterberg, 1995; Monecke, 2005; Sadeghi et al., 2012a), concentration-volume (C-V: Afzal et al., 2011), concentration-distance (C-D: Li et al., 2003) concentration-area; concentration-perimeter (C-A and C-P: Cheng et al., 1994) and concentration-number (C-N: Hassanpour and Afzal, 2013).

\section{Materals and Methods}

\subsection{Sampling and Analysis}

To start geochemical studies in the Khoy 1:100.000 sheet, 1010 data samples (Figure 1) of the stream sediments were selected and analyzed for 44 elements by ICP-MS method by ALS Chemex (ALS Canada Ltd). Detection limits for $\mathrm{Cr}$, Co and $\mathrm{Ni}$ are $10 \mathrm{ppm}, 1 \mathrm{ppm}$ and $2.5 \mathrm{ppm}$ respectively. Moreover, 100 randomized samples were selected and analyzed for assay quality assurance and quality control with respect to Thompson-Howarth error analysis (1976; 1978). Based on the method, the error analysis for $\mathrm{Cr}$ is less than $10 \%$ and about $3 \%$. Among these elements, $\mathrm{Cr}, \mathrm{Co}$ and $\mathrm{Ni}$ were studied to identify the appropriate areas for $\mathrm{Cr}$. In this study $\mathrm{C}-\mathrm{N}$ and $\mathrm{C}-\mathrm{A}$ fractal models were used. After considering the two methods, factor analysis is performed to evaluate the paragenesis and high grade anomalies.

\subsection{Concentration-number (C-N) Fractal Method}

The C-N method was established by Mandelbrot (1983) and developed by Hasanpour and Afzal (2013) to classify various natural phenomena. Agterberg (1995) and Monecke (2005) have developed this method in the earth sciences. This model has the following general form (Deng et al., 2010; Mandelbrot, 1983; Sadeghi et al., 2012a):

$$
\mathbf{N}(\geq \rho) \propto \propto \rho^{-\beta} \rho^{-\beta}
$$

In this equation, $\beta$ is the fractal dimension, $\rho$ denotes element concentration, and $\mathrm{N}$ is the number of samples containing the concentration greater than or equal to $\rho$. This method is based on the inverse proportion between concentration and cumulative frequency of each grade and higher grades. In other words, when the concentration of the element is high, the number of the containing samples is low. The advantages of this method are using raw data (Mandelbrot, 1983; Deng et al., 2010).

\subsection{Concentration-area (C-A) Fractal Method}

The C-A fractal method was established by Cheng et al. (1994) who studied the area located in the Mitchel-Sulphurets porphyry copper deposit in the NW British Columbia, Canada. This method is based on the changes in the concentrations and contained area and higher grades. In other words, there is an inverse relationship between the concentration of the elements and the area occupied by them (Cheng et al., 1994). This means that if the concentrations of the elements are increased, the occupied area by them is reduced. This model has the following relationship (Cheng et al., 1994; Sadeghi et al., 2012b):

$$
\begin{aligned}
& \mathrm{A}(\rho \leq \rho \leq v) \propto \rho^{-a_{1}} \propto \rho^{-a_{1}} ; \mathrm{A} \rho(\rho \geq \rho \leq v) \\
& \propto \rho^{-a_{2}} \propto \rho^{-a_{2}}
\end{aligned}
$$

where $\alpha$ denotes the fractal dimension, $\rho$ shows the element concentration, and A represents the area which is occupied by elements with concentration values less than or equal to and greater than or equal to the contour value $\rho$.

\subsection{Factor Analysis}

The purpose of factor analysis as one of the most popular multivariate analyses is to classify and reduce the number of geochemical variables. It is a useful tool for combining several correlated variables into a single variable and thus for reducing the dimensionality of datasets into uncorrelated principal components based on covariance or correlations of variables which represents the inter-relationships among the multi-dimensional variables. Based on this method, a large dataset of geochemical variables 

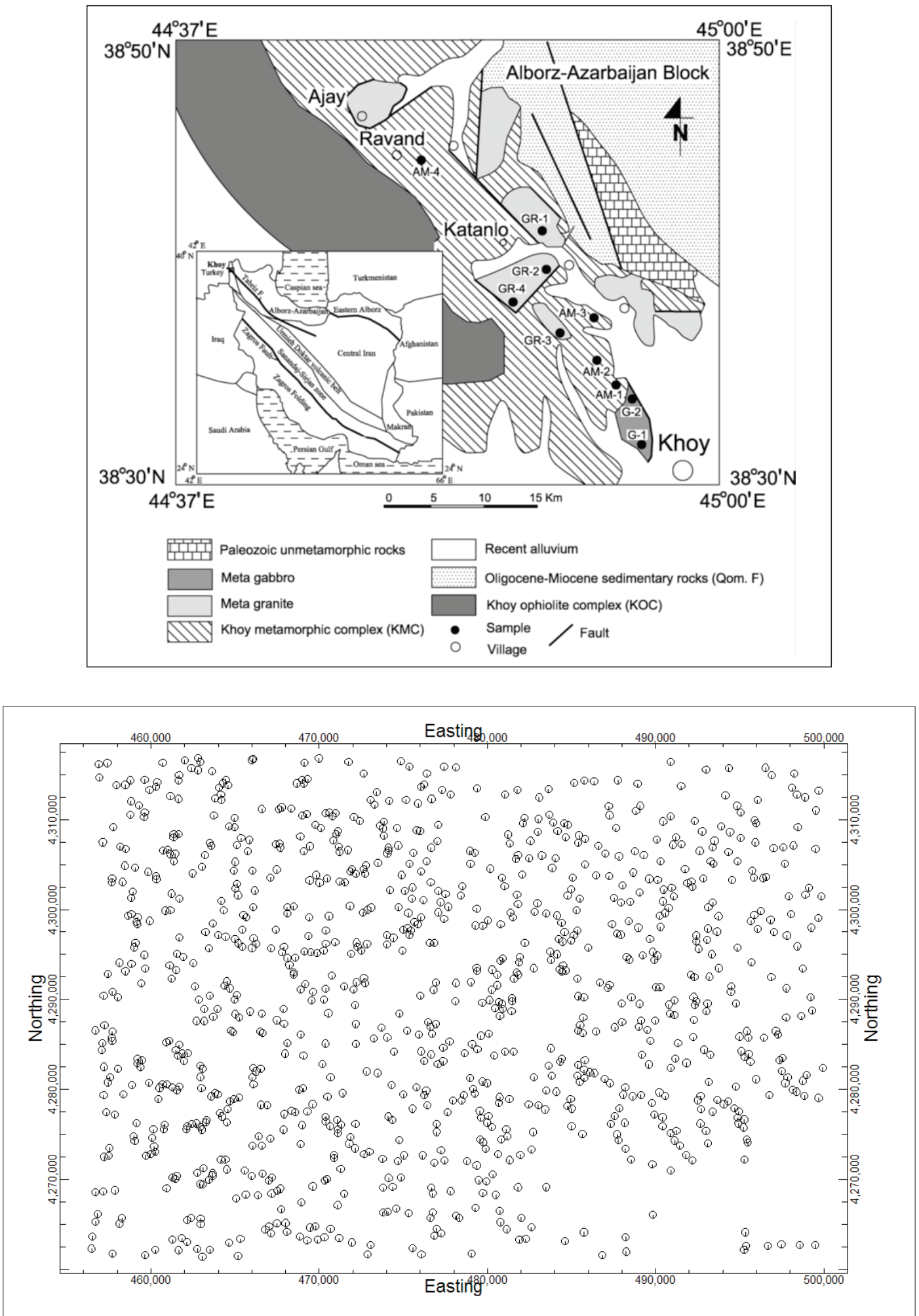

Figure 1- Geological map of Khoy 1:100.000 sheet and its situation in the geological setting of Iran (Alavi, 1994) within samples of chromite occurrences and stream sediments geochemical samples. 
are combined in a few factors (Reimann et al., 2005; Shamseddin Meygoni et al., 2014). Factor analysis under a hypothetical model can find a specific relation between a series of various variables which seem unrelated together. The number of agents (linear combination of the main variables that means specific characteristic of relations between variables) is much less than the number of main variables. Hence, one of the main purposes of this method is to reduce the dimension of data. The basic hypothesis in this method is that there is a fundamental pattern or specific model in the determination of the relating complex concepts between variables. This relation reveals a factor in this hypothetical model and generally the main objective of this method is identification of the variables which are the main controller among a series of geochemical data (Afzal et al., 2013).

Moreover, the elements were classified using factor analysis by SPSS software package. It was carried out using principal component analysis (PCA) with varimax rotation. This classification has been evaluated in the form of the paragenesis factors. All existing elements were examined, and six factors were obtained. The amount of all elements in each factor was clear and higher than 0.6. There are three elements of $\mathrm{Cr}, \mathrm{Co}$ and $\mathrm{Ni}$ in factor 1 . In factor 2, the amount of $\mathrm{Cu}, \mathrm{Sc}$ and $\mathrm{V}$ were above 0.6. In factor 3, the amount of $\mathrm{Ba}, \mathrm{Ga}, \mathrm{Sr}$ and $\mathrm{Y}$ were more than 0.6. In factors 4, 5 and 6, just the amounts of $\mathrm{Pb}, \mathrm{Be}$ and $\mathrm{Mo}$ were above 0.6 , respectively. The investigation of the all factors presents that factor 1 has the elements that they are paragenesis altogether. Statistical parameters of factor 1 (F1) show in the table 1.

Table 1- Summary statistics of Cr, Co, Ni and F1.

\begin{tabular}{|c|c|c|c|c|}
\hline $\begin{array}{c}\text { Statistical } \\
\text { parameters }\end{array}$ & $\mathrm{Cr}(\mathrm{ppm})$ & $\mathrm{Co}(\mathrm{ppm})$ & $\mathrm{Ni}(\mathrm{ppm})$ & $\mathrm{F} 1$ \\
\hline $\begin{array}{c}\text { Detection } \\
\text { Limit }\end{array}$ & 10 & 1 & 2.5 & - \\
\hline Mean & 481.74 & 48.79 & 316.37 & 3.12 \\
\hline Median & 350 & 38 & 138 & 2.25 \\
\hline Variance & 184680.013 & 1803.87 & 224883.44 & 0.02 \\
\hline Maximum & 2000 & 560 & 2000 & 10.8 \\
\hline Minimum & 34 & 4.15 & 3.089 & -2.21 \\
\hline $\begin{array}{c}\text { Standard } \\
\text { deviation }\end{array}$ & 429.744 & 42.47 & 474.22 & 0.15 \\
\hline
\end{tabular}

2.5. Geological Setting of the Khoy 1:100.000 Sheet

The Khoy 1:100,000 sheet is located in NW Iran. The study area is situated in the Alborz-Azerbaijan block which is in NE and SE parts of the Arabian Plate (Stocklin and Nabavi, 1972). The geological map of the study area shows that the KMC is positioned between the Khoy ophiolite complex (KOC) in the west that is overlain on the Arabian plate and Paleozoic unmetamorphosed sedimentary rocks of the AA Block in the east (Ghoraishi and Arshadi, 1987; Radfar and Amini, 1999; Azizi et al., 2006). There are metamorphic rock units with a combination of gneiss, migmatites and quartzite. All regional faults have NW-SE trends with Late Cretaceous age and probably between Upper Cretaceous and Paleocene.

According to the division of the sedimentary structural blocks of Iran (Stocklin 1968), the building blocks are divided into two parts: 1- colored melange zones and 2- Alborz - Azerbaijan region that consists of two areas which are Zurabad (the colored mélange zones) and Ishgeh-su (the Alborz - Azerbaijan region). The area contains the outcrops of sedimentary rocks and metamorphic, volcanic lavas. The range can be observed of metallic and non-metallic minerals. Metallic elements such as $\mathrm{Cu}, \mathrm{Zn}, \mathrm{Pb}, \mathrm{Cr}$, $\mathrm{Co}$ and $\mathrm{Ni}$ and non-metallic minerals such as talc, asbestos, graphite, feldspar and magnesia. According to the elemental histogram, there is a similar distribution for $\mathrm{Cr}$ and Ni (Figure 2).

\section{Discussion}

Table 1 shows the mean, median, variance, maximum, minimum, and standard deviation. The distribution of each element is shown in figure 2 . Concentrations of $\mathrm{Cr}, \mathrm{Co}$, and $\mathrm{Ni}$ have wide ranges and high standard deviations, as depicted in table 1.

In fractal modeling, the logarithmic plot is used for finding the threshold of host rocks and mineralized zones. The slope of the fitted line segments to the data points represents the fractal dimension. Using the obtained thresholds, high grade anomalies can be identified and distinguished easily. In table 2, threshold values of elements and factor analysis were calculated based on the C-N log-log graphs. 

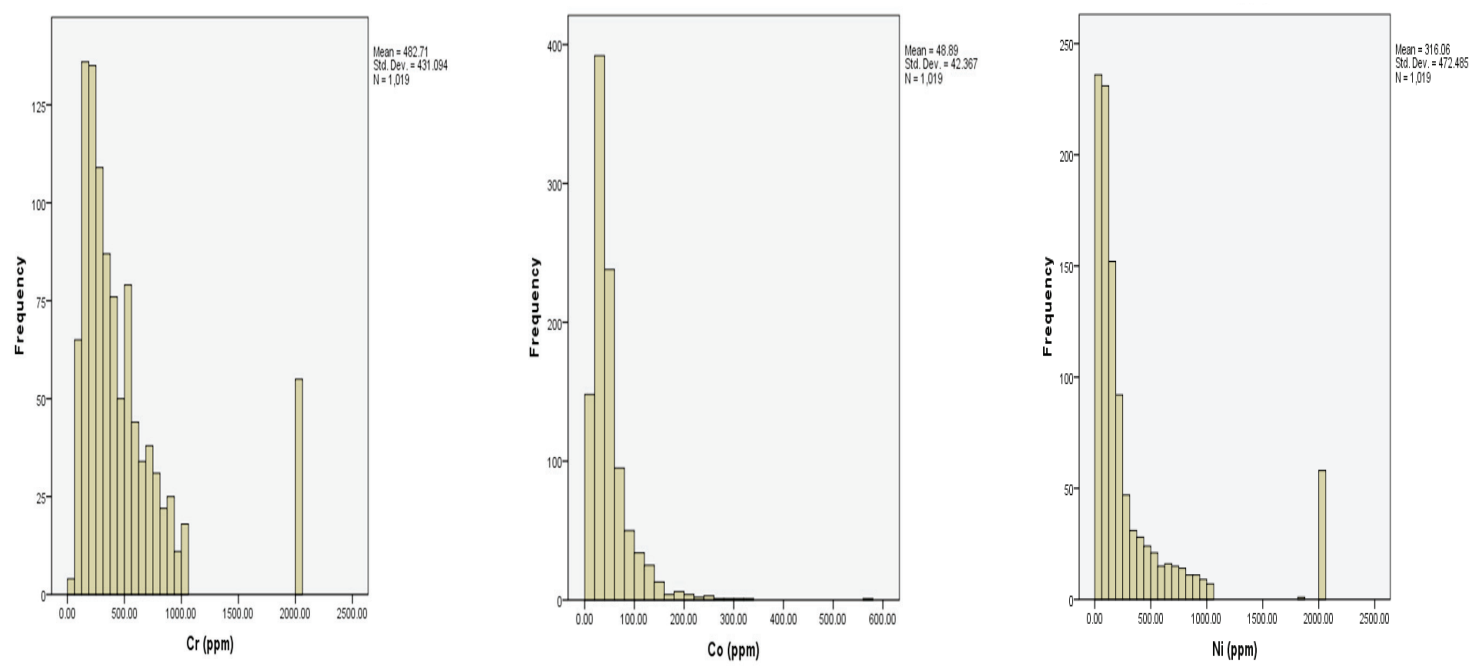

Figure 2- Histogram of $\mathrm{Cr}$, $\mathrm{Co}$ and $\mathrm{Ni}$ in the study area.

Table 2- Threshold values based on C-N fractal models.

\begin{tabular}{|c|c|c|c|c|}
\hline Very high & High & Moderate & Low & \multirow{2}{*}{} \\
\cline { 1 - 4 } intensity & intensity & intensity & intensity & \multirow{2}{*}{ Element } \\
\cline { 1 - 4 } threshold & threshold & threshold & threshold & \\
\hline 630.95 & - & - & 177.82 & \multirow{2}{*}{$\mathrm{Cr}(\mathrm{ppm})$} \\
\hline 123.02 & - & 40.73 & 17.78 & $\mathrm{Co} \mathrm{(ppm)}$ \\
\hline 954.99 & - & 602.55 & 125.89 & $\mathrm{Ni}(\mathrm{ppm})$ \\
\hline 3.162 & - & 1.778 & 0.125 & $\begin{array}{c}\text { Factor 1 } \\
\text { (ppm) }\end{array}$ \\
\hline
\end{tabular}

Based on the C-N log-log plots, there are two thresholds and three populations for $\mathrm{Cr}$, as depicted in figure 3. The C-N log-log plots represent the three breakpoints and four concentration populations for $\mathrm{Co}, \mathrm{Ni}$ and factor 1 (Figure 3). The factor 1 includes $\mathrm{Cr}$, Ni and $\mathrm{Co}$ that fractal modelling for this factor shows $\mathrm{Cr}$, Ni and $\mathrm{Co}$ anomalies with them. High intensive anomalies for $\mathrm{Cr}$, $\mathrm{Ni}$ and $\mathrm{Co}$ commenced from $630.95,954.99$ and 123.02 ppm respectively, as depicted in table 2 .

The Results of the C-A method display that the $\mathrm{Cr}$ and $\mathrm{Co}$ have two threshold values but $\mathrm{Ni}$ has three threshold values. However, the C-A log-log plot for factor1 reveals four threshold values (Figure 4). The characteristics of the anomalous thresholds are expressed in table 3.
Table 3- Threshold values based on C-A fractal model.

\begin{tabular}{|c|c|c|c|c|}
\hline Element & Very high & High & Moderate & Low \\
& intensity & intensity & intensity & intensity \\
& threshold & threshold & threshold & threshold \\
\hline Cr (ppm & 501.18 & - & - & 35.48 \\
Co (ppm) & 1258.92 & - & 575.43 & 125.89 \\
Ni (ppm) & 9.12 & 5.011 & 3.162 & 0.794 \\
\hline
\end{tabular}

Sudden changes in the C-A log-log plot shows that exchanging in the populations and anomalies. High in intensive anomalies of $\mathrm{Cr}$, $\mathrm{Co}$ and $\mathrm{Ni}$ began from $1778.27,501.18$ and $1258.92 \mathrm{ppm}$ respectively, as shown in table 3.

\subsection{Comparison of the C-N and C-A Fractal Models}

Comparison between results obtained by the fractal models reveals that the threshold values derived via the C-A method are higher than the C-N threshold values. On the other hand, the areas of high intensive anomalies obtained by $\mathrm{C}-\mathrm{N}$ fractal modelling are greater than the $\mathrm{C}-\mathrm{A}$ fractal modelling. It is worth to note that the discipline of the C-N method is based on irregularities, so calculations obtained from this 

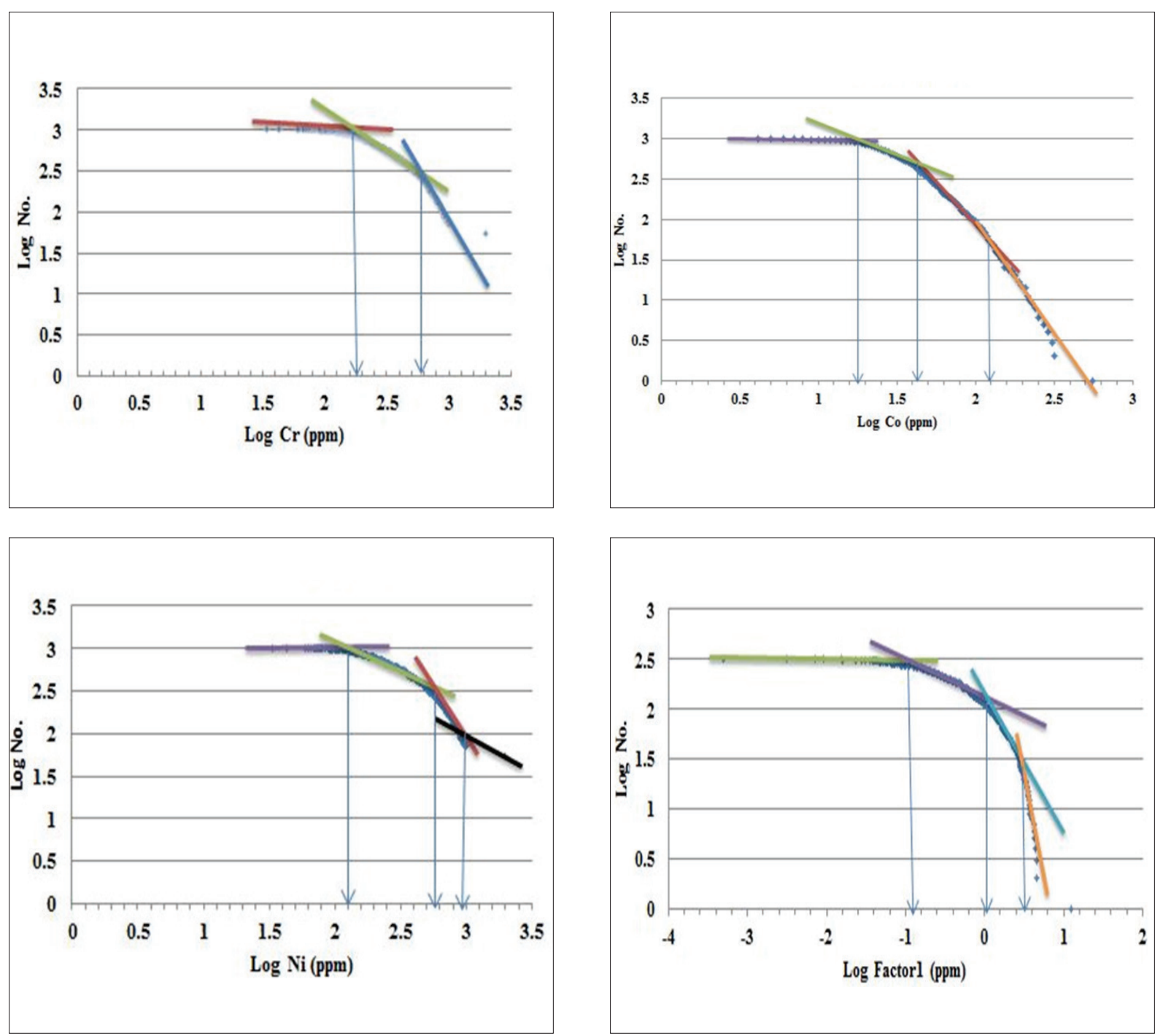

Figure 3- C-N log-log plots for $\mathrm{Cr}, \mathrm{Co}$, Ni and factor 1 in the Khoy sheet.

method also follows the principle of this method. This fact leads to obtain a better logical estimation. On the other hand, in the C-A method because of the fact that certain irregularities are governing in obtaining the area and mineral aggregate are neither in order or regular, therefore this method cannot estimate exact and logical unless the network of surveyed data is organized and this means that the interval of sampling network is not less than or greater than other areas since this method estimates all areas and if the gap enlarged, the error increases as well.

\subsection{Spatial Distribution of the Elements}

Based on the obtained thresholds, the spatial distribution maps of the elements were generated using IDW algorithm by the Rockworks software. The high intensive anomalies derived by the both fractal models are located in the central and SW parts of the area especially for $\mathrm{Cr}, \mathrm{Ni}$ and factor1. The Co main anomalous parts occurred in the central part of the area based on the fractal modelling (Figure 5).

All three elements are in a good agreement with each other and they are aggregated in the central parts of the map in addition little in the SE. The detailed investigation of each map shows that a large amount of $\mathrm{Cr}$ is located in the center of the map and a little less in the southwest of the map. The accumulation of Co is in the central part of the map, and the dispersion of $\mathrm{Ni}$ is the same as $\mathrm{Cr}$, which means it is located in the central and southwestern parts of the map. In the spatial distribution map of the factor analysis, based on the factor maps, it can be found that the accumulations of all three elements are in the central and SW parts of the study area (Figure 5). 

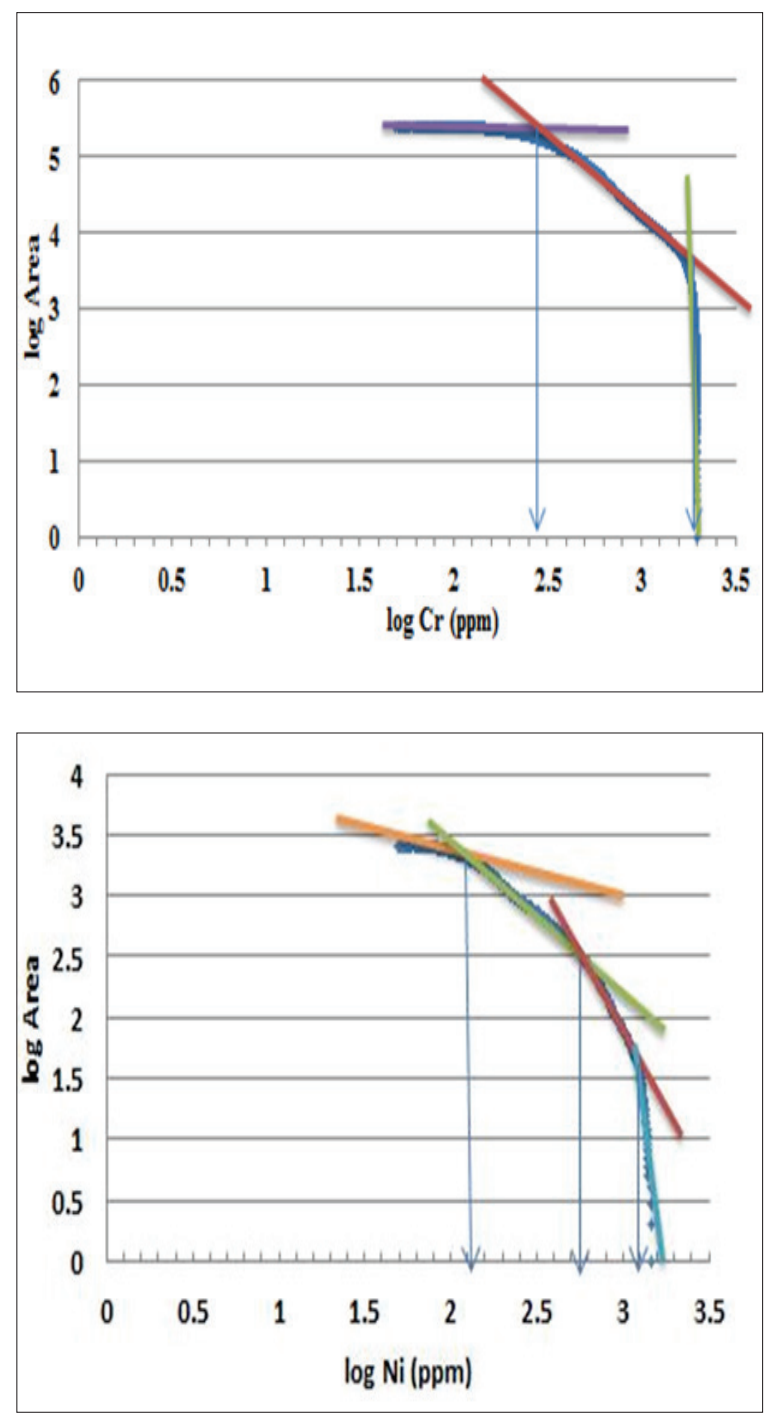

Figure 4- C-A log-log plat for $\mathrm{Cr}, \mathrm{Co}, \mathrm{Ni}$ and factor 1 in Khoy sheet.

\section{Conclusions}

In conclusion, as far as the issue of economic geology, there are two identified areas which are more important than the other parts. These parts are located in the central and western parts of the Khoy geological sheet. In these areas, the accumulation of minerals contains $\mathrm{Cr}$ and its paragenesis, and therefore they are recognized as the high grade and promising areas of detailed exploration. Comparison between results derived via the fractal models indicates that the threshold values obtained by the C-A method are higher than the $\mathrm{C}-\mathrm{N}$ threshold values. On the other hand, the areas of high intensive anomalies obtained by the $\mathrm{C}-\mathrm{N}$ fractal modelling are greater than the $\mathrm{C}$-A fractal modelling. The high intensive anomalies obtained by the both fractal models are situated in
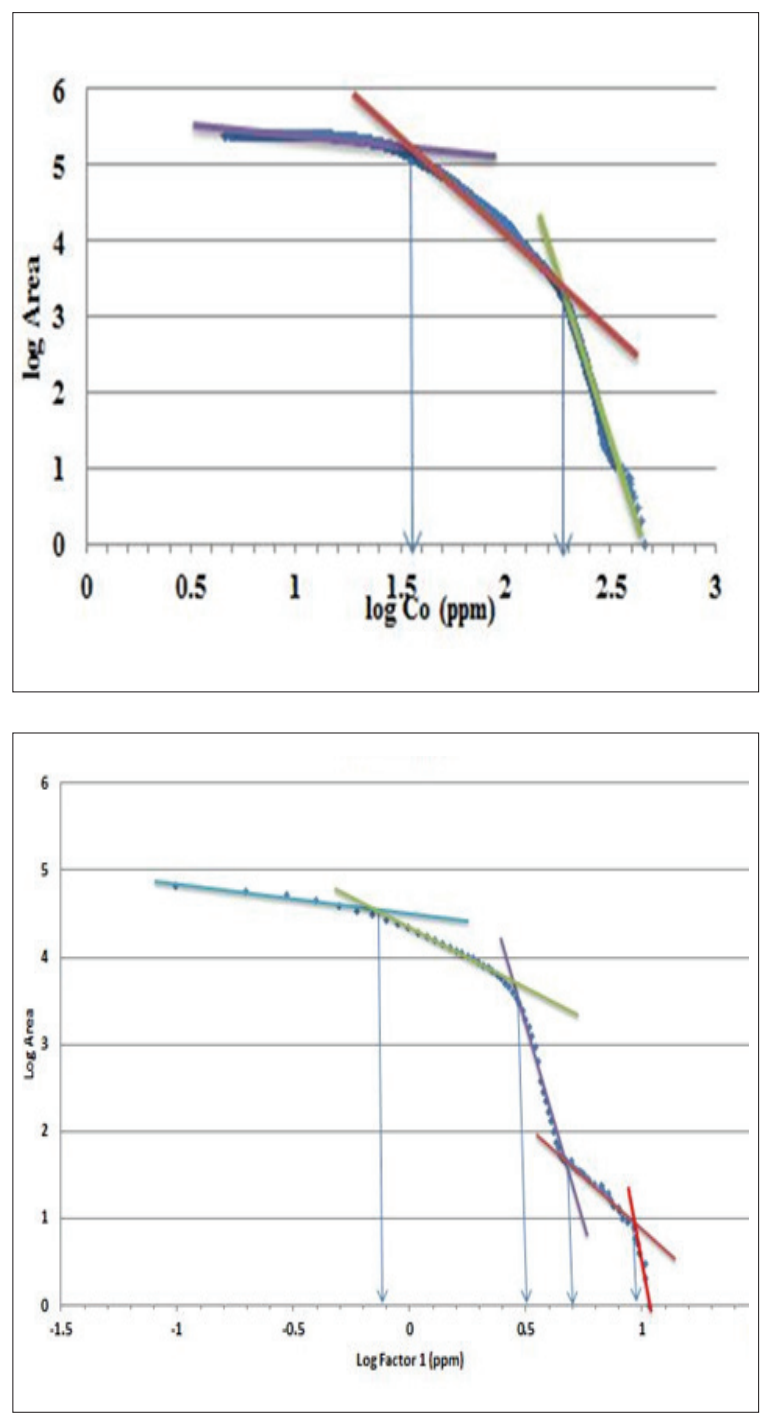

the central and SW parts of the area especially for $\mathrm{Cr}$ and $\mathrm{Ni}$. Besides, the evaluation of the factor analysis confirms the detailed analysis of the elements. Aggregation place of these elements is in accordance with the geological map. These places are mostly in the place of ultramafic rocks of serpentinite contain harzburgite and dunite that small amounts of the elements are related to the lithology of amphibolite rocks consistent with amphibolite schist, mica schist, marble cut by quartz-feldspathic veins and aplite. In assessing these two methods ( $\mathrm{C}-\mathrm{N}$ and $\mathrm{C}-\mathrm{A})$ it is realized that all obtained thresholds and populations were close to each other. It is identified in the factor analysis by both methods. It is pretty obvious in the histogram of the factor analysis that the aggregations of the paragenesis elements all together are exactly the same as those of each individual element. 


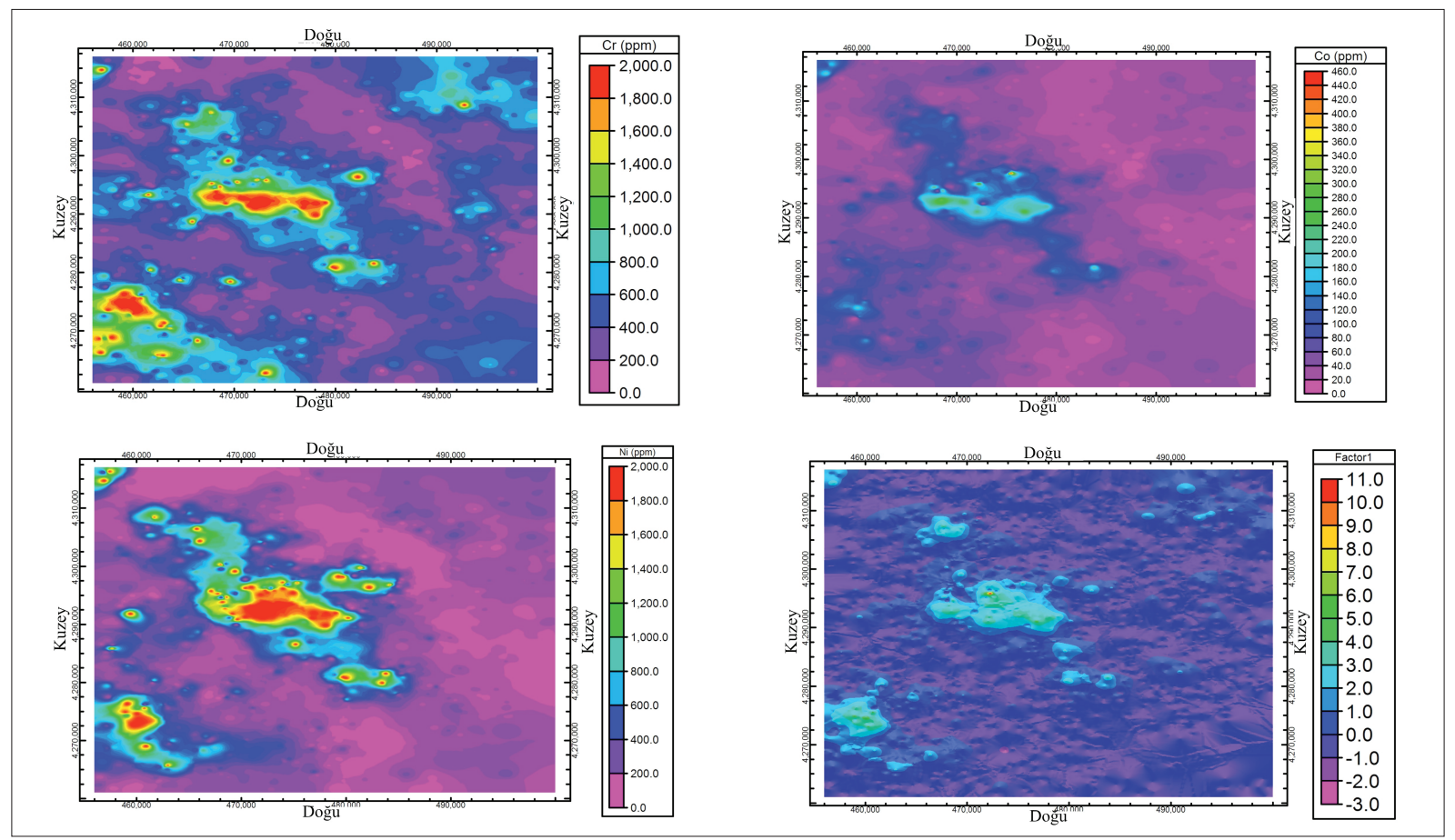

Figure 5- Geochemical maps obtained from the N-S fractal modelling for $\mathrm{Cr}, \mathrm{Co}, \mathrm{Ni}$ and factor 1.

\section{Acknowledgements}

The authors would like to thank Mr. Seyed Ali Hosseini for his great helpful information in this research.

\section{References}

Afzal, P., Zia Zarifi, A., Sadeghi, B. 2013. Separation of Geochemical Anomalies Using Factor Analysis and Concentration-Number (C-N) Fractal Modeling Based on Stream Sediments Data in Esfordi 1:100000 Sheet, Central Iran, Iranian Journal of Earth Sciences, Vol. 5, p.p. 100-110.

Afzal, P., Fadakar Alghalandis Y., Khakzad A., Moarefvand P., Rashidnejad, N. 2011. Delineation of mineralization zones in porphyry $\mathrm{Cu}$ deposits by fractal concentration-volume modeling. Journal of Geochemical Exploration 108: 220-232.

Afzal, P., Khakzad, A., Moarefvand, P., Rashidnejad Omran, N., Esfandiari, B., Fadakar Alghalandis, Y. 2010. Geochemical anomaly separation by multifractal modeling in Kahang (GorGor) porphyry system, Central Iran. Journal of Geochemical Exploration 104: 34-46.
Agterberg, FP. 1995. Multifractal modeling of the sizes and grades of giant and supergiant deposits. Int Geol Rev 37:1-8Azizi, H., Moinevaziri, H., Mohajjel, M., Yagobpoor, A., 2006. PTt path in metamorphic rocks of the Khoy region (northwest Iran) and their tectonic significance for Cretaceous-Tertiary continental collision. Journal of Asian Earth Science, 27, 1-9.

Azizi, H., Moinevaziri, H., Mohajjel, M., Yagobpoor, A. 2006. PTt path in metamorphic rocks of the Khoy region (northwest Iran) and their tectonic significance for Cretaceous-Tertiary continental collision. Journal of Asian Earth Science 27, 1-9.

Cheng, Q., Agterberg FP, Ballantyn, SB. 1994. The separartion of geochemical anomalies from background by fractal methods. Journal of Geochemical Exploration 51:109-130.

Deng, J., Wang, Q., Yang, L., Wang, Y., Gong, Q., Liu, H. 2010. Delineationand explanation of geochemical anomalies using fractal models in the Heqing area, Yunnan Province, China. Journal of Geochemical Exploration. 105:95-105. 
Ghoraishi, M., Arshadi, S. 1987. Geology Map of Khoy Quadrangle (1:250,000). Geology Survey of Iran.

Hassanpour, S., Afzal, P. 2013. Application of concentrationnumber (C-N) multifractal modelling for geochemical anomaly separation in Haftcheshmeh porphyry system, NW Iran. Arabian Journal of Geosciences, vol. 6, pp. 957-970.

Li, Changjiang Ma, Tuhua Shi, Junfa. 2003. Application of a fractal method relating concentrations and distances for separation of geochemical anomalies from background. Journal of Geochemical Exploration, 77: 167-175.

Mandelbrot, B.B. 1983. The fractal geometry of nature. Freeman, San Francisco, pp 1-468.

Meng, X., Zhao, P. 1991. Fractal method for statistical analysis of geological data, Chinese Journal of Geosciences, vol. 2, pp. 207-211.

Mohammadi, A., Khakzad, A., Rashidnejad Omran, N., Mahvi, M.R., Moarefvand, P., Afzal, P. 2013. Application of number-size $(\mathrm{N}-\mathrm{S})$ fractal model for separation of mineralized zones in DarehAshki gold deposit, Muteh Complex, Central Iran. Arabian Journal of Geosciences. 6: 4387-4398.

Monecke, T., Monecke, J., Herzig, P.M., Gemmell, J.B., Monch, W. 2005. Truncated fractal frequency distribution of element abundance data: a dynamic model for the metasomatic enrichment of base and precious metals. Earth and Planet. Sci. Lett., 232: 363-378.

Radfar, J., Amini, B. 1999. Geology Map of the Khoy Quadrangle (1:100,000). Geological Survey of Iran.

Rafiee, A. 2005. Separating geochemical anomalies in stream sedimentmedia by applying combination of fractal concentration area model and multivariate analysis (Case study: Jeal-e-Barez 1:100,000 Sheet, Iran), 20 $0^{\text {th }}$ World Mining Congress Proceedings, Iran, 461-470.
Reimann, C., Filzmoser, P., Garrett, R.G. 2005. Background and threshold: critical comparison of methods of determination. Sci. Total Environ., 346, 1-16.

Turcotte, D.L. 1986. A fractal approach to the relationship between ore grade and tonnage. Econ. Geol. 18: 1525-1532.

Sadeghi, B., Moarefvand, P., Afzal, P., Yasrebi, A.B., Daneshvar Saein, L. 2012a. Application of fractal models to outline mineralized zones in the Zaghia iron ore deposit, Central Iran. Journal of Geochemical Exploration .Special Issue "fractal/ multifractal modelling of geochemical data”, 122: 9-19.

Sadeghi, B., Afzal, P., Moarefvand, P., Khoda Shenas, N., 2012b. Application of concentration-area fractal method for determination of $\mathrm{Fe}$ geochemical anomalies and the background in Zaghia area, Central Iran. $34^{\text {th }}$ International Geological Congress (IGC), Brisbane, Australia.

Shamseddin Meigoony, M., Afzal, P., Gholinejad, M., Yasrebi, A.B., Sadeghi, B. 2014. Delineation of geochemical anomalies using factor analysis and multifractal modeling based on stream sediments data in Sarajeh 1:100000 sheet, Central Iran, Arabian Journal of Geosciences, 7, 5333-5343.

Stocklin, J. 1968. Structural history and tectonics of Iran: a review. AAPG Bulletin, 52, 1229-1258.

Stocklin, J., Nabavi, M. 1972. Tectonic Map of Iran. Geological Survey of Iran.

Thompson, M., Howarth, R.J. 1976. Duplicate analysis in geochemical practice (2 parts). Analyst, 101, 690709.

Thompson, M., Howarth, R.J. 1978. Anew approach to the estimation of analytical precision. Journal of Geochemical Exploration 9, 23-30. 
